\title{
Campur Kode dalam Novel Kami (Bukan) Sarjana Kertas Karya J.S. Khairen
}

\author{
Sulfiana ${ }^{1}$, Cintya Nurika Irma ${ }^{2}$ \\ PBI, FKIP, Universitas Peradaban \\ fiasulfiana8@gmail.com ${ }^{1}$,Cintya_nurikairma@yahoo.co.id ${ }^{2}$
}

DOI: https://doi.org/10.32528/bb.v5i2.2723

First received: 29-11-2019 Final proof received: 29-09-2020

\begin{abstract}
ABSTRAK
Tujuan dari penelitian ini yaitu untuk mengetahui arah campur kode pada novel Kami (Bukan) Sarjana Kertas karya J.S. Khairen. Metode penelitian yang digunakan adalah metode penelitian deskriptif kualitatif. Data dan Sumber data yang digunakan adalah campur kode yang terdapat dalam novel Kami (Bukan) Sarjana Kertas karya J.S Khairen tahun terbit 2019 dengan jumlah halaman 364 halaman, diterbitkan oleh penerbit PT Bukune Kreatif Cipta. Teknik pengumpulan data dilakukan menggunakan teknik pustaka. Guna menguji keabsahan data digunakan triangulasi yaitu melalui pemeriksaan sumber data, teori yang digunakan, dan metode dalam penelitian. Hasil penelitian menunjukkan terdapat dua arah campur kode, yaitu : campur kode ke dalam dan campur kode ke luar. Campur kode ke dalam terdapat percampuran antara bahasa Indonesia dengan bahasa Jawa dan bahasa Indonesia dengan bahasa Betawi. Selanjutnya, campur kode ke luar terdapat dua arah yaitu peggunaan bahasa Indonesia dengan bahasa Arab dan bahasa Indonesia dengan bahasa Inggris. Percampuran tersebut terjadi pada percakapan yang terjadi antara tokoh dengan menggambarkan kehidupan ibu kota Jakarta, khususnya keharusan dalam mempelajari dan mampu menggunakan bahasa Inggris dalam kehidupan sehari-hari, tetapi penerapannya belum bersesuaian artinya dilakukan pencampuran bahasa asing dengan bahasa keseharian atau bahasa ibu sebagai bentuk keakraban yang mengakibatkan terjadinya campur kode dalam berkomunikasi termasuk yang dilakukan di dalam novel.
\end{abstract}

Kata kunci: sosiolinguistik; campur kode; novel

\begin{abstract}
The purpose of this study is to determine the direction of code mixing in the novel Kami (Bukan) Sarjana Kertas of J.S. Khairen. The research method used is descriptive qualitative research methods. Data and Source of data used is a mixed code that is contained in the novel Kami (Bukan) Sarjana Kertas of J.S Khairen year of issue 2019 with the number of pages 364 pages, published by publisher PT Bukune Creative Copyright. The technique of data collection is done using the technique of the
\end{abstract}


literature. In order to test the validity of data used triangulation, namely through the examination of sources of data, theories used, and methods in research. The results showed a significant two-way mixed code, ie : mix the to in and mix the code to the outside. Mix the code in there is mixing between Indonesia and Javanese language and Indonesian language with Betawi. Furthermore, the mixed code to the outside there are two directions that use Indonesian language with Arabic and Indonesian language with the English language. Mixing occurs on the conversation that occurs between the figures to describe the life of the capital city of Jakarta, especially the necessity to learn and being able to use English in everyday life, but its application have not been consistent that is done mixing a foreign language with the everyday language or the language of the mother as a form of familiarity which resulted in the occurrence of code mixing in communication including that done in the novel.

Keywords: sociolinguistics, code mixing, novel

\section{PENDAHULUAN}

Bahasa sebagai alat komunikasi diperlukan dalam interaksi. Selain sebagai alat komunikasi, bahasa juga digunakan sebagai alat identifikasi diri serta untuk memudahkan proses kerja sama antar anggota kelompok sosial atau masyarakat. Pentingnya penggunaan bahasa sebagai alat komunikasi perlu diketahui oleh semua pihak yang terlibat dalam proses komunikasi tersebut. Pihak yang terlibat dalam proses komunikasi perlu saling memahami bahasa serta maksud yang hendak disampaiikan.

Seperti yang kita ketahui, di Indonesia memiliki ragam bahasa daerah yang tersebar di seluruh penjuru nusantara. Penggunaaan bahasa daerah yang masih melekat dan susah dihilangkan oleh penutur menyebabkan percampuran bahasa sering terjadi dalam proses komunikasi. Percampuran bahasa daerah dengan bahasa Indonesia sering dilakukan oleh masyarakat Indonesia dalam komunikasi, sehingga semua pihak yang terlibat dalam komunikasi tersebut harus saling memahami bahasa yang digunakan agar dalam proses komunikasi tersebut berjalan dengan lancar.

Kemampuan menggunakan dua bahasa dalam komunikasi dapat disebut dengan bilingualisme atau kedwibahasaan. Bilingualisme tidak hanya digunakan untuk menyebut pengguna bahasa yang menguasai dua bahasa saja tetapi seseorang dapat disebut sebagai bilingualisme jika menguasi empat bahasa tetap (Nasruddin, 2015: 46). Chaer dan Agusitna (2014: 84) menyebutkan bahwa untuk dapat menggunakan dua bahasa, seseorang harus menguasai kedua bahasa tersebut.

Pada proses komunikasi terdapat hal yang perlu diperhatikan yakni penguasaan bahasa yang digunakan. Bila tidak mengetahui bahasa yang digunakan akan sulit memahami makna serta maksud pesan yang disampaikan. Selain itu, pemahaman bahasa secara baik dan benar akan menjadikan maksud pesan mitra tutur tersampaikan sesuai harapan. Oleh karena itu, diperlukan mempelajari bahasa mitra tutur yang belum dikuasai tersebut. 
Selain percampuran bahasa daerah dengan bahasa Indonesia, penggunaan dua bahasa ini juga dapat terjadi antara bahasa Indonesia dengan bahasa asing. Percampuraan penggunaan dua bahasa disebut dengan istilah campur kode. Kode yang terjadi berdasarkan dari latar belakang penutur, mitra tutur, dan konteks dalam tuturan (Mutmainnah, 2008: 28). Campur kode yang dilakukan ini mengacu pada varian dalam bahasa yang digunakan (Malabar, 2015: 46).

Terdapat unsur-unsur dalam kode bahasa seperti fonem, morfem, kata, dan kalimat yang memiliki bentuk, distribusi, dan frekuensi unsur-unsur bahasa tersebut. Mulyani dan Haryanti (2015: 48) menyatakan ragam bahasa santai terjadi pada penutur dan mitra tutur yang telah dikenal akrab dengan situasi santai. Terkadang mengakibatkan terjadinya perubahan variasi dan kode yang dilakukan dengan bahasa lain (Rosnaningsih, 2019: 26),

Selanjutnya, Maulina, dkk. (2018: 1) menambahkan campur kode merupakan suatu peristiwa percampuran dua atau lebih bahasa pada situasi atau konteks tertentu. Percampuran bahasa tersebut bertujuan untuk menambahkan kejelasan terhadap konteks atau maksud yang ingin disampaikan dalam komunikasi. Dengan demikian, dapat disimpulkan bahwa dalam campur kode lebih menitikberatkan pada penggunaan satuan bahasa ke dalam bahasa lain berdasarkan situasi tertentu.

Sehubungan dengan pendapat di atas, Chaer (2012: 69) menjelaskan bahwa dalam campur kode terdapat dua kode atau lebih yang digunakan secara bersama tanpa alasan karena tidak terjadi pada situasi resmi. Murliaty, dkk. (2013: 283) menyepakati bia ciri khas campur kode terjadi pada konteks informal. Penggunaan campur kode dalam situasi formal jarang digunakan dan jika digunakan percampuran kode dalam situasi formal disebabkan oleh tidak adanya ungkapan yang tepat dalam bahasa yang sedang digunakan, sehingga diperlukan pemakaian kata atau ungkapan dari bahasa daerah atau bahasa asing.

Campur kode merupakan pengguaan dua kode atau bahasa yang dilakukan secara bersamaan dalam situasi santai. Peristiwa campur kode terjadi akibat beberapa faktor, salah satunya yaitu karakteristik dari penutur. Hal tersebut senada dengan pendapat Wardani (2017: 75) bahwa penyebab terjadinya campur kode disebabkan penguasaan kosakata yang masih kurang dari penutur, sehingga mencari kata yang memiliki makna yang sama dari bahasa lain. Terjadinya campur kode minimal menyisipkan kata dari bahasa lain yang menduduki satu fungsi.

Berbeda dengan pendapat Wardani, Rokhman (2013: 38) menjelaskan bahwa penyebab terjadinya peristiwa campur kode yaitu adanya penyisipan unsur-unsur atau variasi bahasa lain yang tidak berdiri sendiri. Unsur- unsur itu sudah menyatu dengan bahasa yang disisipinya serta secara keseluruhan hanya menunjang satu fungsi. Di dalam keadaan yang optimal campur kode ialah konvergensi kebahasaan( linguistic convergence) yang unsur- unsurnya berasal dari sebagian bahasa yang masing- masing sudah menanggalkan fungsinya serta menunjang fungsi bahasa yang disisipinya 
Menurut Nursaid dan Maksan (2002: 110-113) campur kode terbagi atas dua arah, yaitu campur kode ke dalam (inner code mixing) dan campur kode keluar (outer code mixing). Campur kode ke dalam (inner code mixing) merupakan tindakan percampuran bahasa Indonesia dengan bahasa lain. Campur kode keluar (outer code mixing) adalah campur kode yang terjadi karena mencampurkan bahasa utama yaitu bahasa Indonesia dengan bahasa asing.

Campur kode tidak hanya terjadi pada komunikasi langsung, tetapi juga dapat terjadi dalam karya sastra seperti novel. Karya sastra yang juga tidak terlepas dari kehidupan manusia karena karya sastra merupakan cerminan dari masyarakat tidak menutup kemungkinan teridentifikasi adanya peristiwa campur kode. Hal tersebut juga ada pada novel Kami (Bukan) Sarjana Kertas karya J.S. Khairen yang dalam ceritanya menunjukan campur kode denXgan menampilkan penggunaan dua bahasa.

Seseorang yang mampu menguasai dua bahasa dengan baik, tetapi juga mampu memiliki tingkatan kemampuan bahasa yang beragam lainnya (Yuliyanti, 2018: 128). Penelitian ini membahas mengenai bagaimanakah campur kode yang terdapat dalam novel Kami (Bukan) Sarjana Kertas karya J.S. Khairen? Selanjutnya, tujuan penelitian ini adalah untuk mengetahui campur kode yang terdapat dalam novel Kami (Bukan) Sarjana Kertas karya J.S. Khairen.

\section{METODE}

Metode penelitian yang digunakan dalam penelitian ini adalah metode penelitian deskriptif. Suryabrata (2012: 76) mendefinisikan penelitian deskriptif bertujuan mendeskripsikan suatu kejadian. Data yang digunakan dalam penelitian ini adalah novel Kami (Bukan) Sarjana Kertas karya J.S Khairen tahun terbit 2019 dengan jumlah halaman 364 halaman, diterbitkan oleh penerbit PT Bukune Kreatif Cipta. Sumber data yang digunakan adalah peristiwa campur kode yang terdapat dalam novel Kami (Bukan) Sarjana Kertas karya J.S Khairen. Teknik pengumpulan data dilakukan menggunakan teknik pustaka yaitu dengan membaca secara kritis isi novel kemudian mencatat data yang menunjukan peristiwa campur kode yang ada dalam novel. Penelitian ini menggunakan triangulasi untuk menguji keabsahan data dengan memanfaatkan sesuatu yang lain seperti sumber, metode, penyidik, dan teori Moleong (2012: 330).

\section{PEMBAHASAN}

Campur kode merupakan perisiwa pemakaian dua bahasa atau lebih secara bersamaan yang terjadi dalam proses komunikasi sudah menjadi hal yang biasa. Hal tersebut dikarenakan masyarakat Indonesia yang termasuk dalam masyarakat bilingual atau pemakai dua bahasa. Pemakaian dua bahasa atau lebih ini selain sering dijumpai dalam proses komunikasi, juga dapat ditemukan dalam novel seperti pada novel Kami (Bukan) Sarjana Kertas karya J.S Khairen. Berdasarkan analisis yang telah dilakukan dalam novel Kami (Bukan) Sarjana Kertas karya J.S Khairen terdapat banyak dialog yang mengandung peristiwa campur kode. 
Pada novel tersebut menunjukan adanya arah campur kode ke dalam (inner code mixing) dan campur kode keluar (outer code mixing). Penelitian mengenai campur kode sebelumnya telah dilakukan oleh beberapa peneliti seperti yang dilakukan oleh Amalia Meldani (2018) dengan judul penelitian "Alih Kode dan Campur Kode dalam Novel The Sweet Sins Karya Rangga Wirianto Putra”. Penelitian tersebut membahas mengenai arah alih kode dan arah campur kode dalam novel The Sweet Sins yang meliputi alih kode ekstern dan alih kode intern yang akan dibahas pula dalam penelitian ini.

Alih kode ekstern adalah alih kode yang di dalam pergantian bahasanya si pembicara mengubah bahasanya dari bahasa satu ke bahasa lain yang tidak sekerabat (bahasa asing). Alih kode intern merupakan suatu alih kode yang terjadi ketika sang pembicara dalam pergantian bahasanya memakai bahasa- bahasa yang masih dalam ruang lingkup bahasa nasional ataupun antardialek dalam satu bahasa daerah ataupun antara sebagian macam dan gaya yang ada dalam satu dialek. Berikut ini penjabaran yang berhubungan dengan campur kode yang ada dalam novel Kami (Bukan) Sarjana Kertas karya J.S Khairen.

\section{a) Arah Campur Kode ke Dalam}

Campur kode ke dalam yaitu campur kode yang terjadi karena penggunaan dua bahasa yaitu dengan mencampurkan bahasa utama yaitu bahasa Indonesia dengan bahasa pertama atau bahasa yang digunakan dalam kehidupan sehari-hari. Terdapat dua arah campur kode ke dalam pada novel Kami (Bukan) Sarjana Kertas karya J.S Khairen yaitu campur kode antara bahasa Indonesia dengan bahasa Jawa dan bahasa Indonesia dengan bahasa Betawi. Campur kode antara bahasa Indonesia dengan bahasa Jawa yang ditemukan berjumlah 5 dialog yang mengandung unsur campur kode dengan bukti kutipan berikut ini.

(1) "Pie iki, bikin robot-robot ndak jelas kok dipuji. Gunanya opo tho?" (KBSK, 2019: 155)

Dalam kutipan 1 di atas digunakan bahasa Jawa ditengah-tengah percakapan yang menggunakan bahasa Indonesia. Hal tersebut termasuk ke dalam percampuran dua bahasa yaitu penggunan bahasa Indonesia dengan bahasa Jawa. Dalam kutipan 2 di bawah ini penggunaan kata "ndak" yang merupakan bahasa Jawa terdapat di antara bahasa Indonesia, hal tersebut membuktikan adanya percampuran dua bahasa yaitu penggunan bahasa Indonesia dengan bahasa Jawa.

(2) "Ya ndak apa-apa, kalau belum siap jawab aja. Kalau sudah ya alhamdulilah,"sergah ayah Juwisa. (KBSK, 2019: 204)

Selanjutnya, campur kode antara bahasa Indonesia dengan bahasa Betawi yang ditemukan dalam novel Kami (Bukan) Sarjana Kertas karya J.S Khairen. Terdapat penggunaan kata "ye" dan "babe" yang merupakan kata khas dari bahasa Betawi yang sering digunakan oleh penutur Betawi. Sumarsono (2007: 67) menyatakan bahasa adalah identitas etnik yang berhubungan dengan kelompok sosial atau kebudayaan yang dijadikan sebagai identitasnya. 
Penunjukkan penggunaan bahasa Betawi "ampe, aje, lu" yang disisipkan dalam bahasa Indonesia. Muhadjir (2000: 62-68) menjelaskan ciri khas bahasa Betawi dapat dilihat dari beberapa sudut pandang, yaitu : (1) dari ciri pelafalan atau tata ucapnya banyak ditemukan vokal é pada kosa kata, contohnya seperti pada kata: apé, adé, ayé, dan lain-lain, (2) pada tataran kata, adanya suffiks \pm in, seperti pada kata: ndatengin, ngumpetin, nguntitin, dan (3) pada tataran tata kalimat banyak menggunakan partikel dong, deh, kok, si, kek, dll. Berikut ini tersurat penggunaan bahasa Betawi dalam kutipan 3 dan 4.

(3) "Ntar kalau udah sukses di Amrik sono, jangan lupa pulang ye. Tengok-tengok adek lo juga. Kuburan babe lo.” (KBSK, 2019: 229)

(4) "Makanya jangan nyanyi mulu. Gue denger ampe jam dua masih nyanyi aje lu. Kaya bakalan jadi artis aje!” (KBSK, 2019: 260)

\section{b) Arah Campur Kode Ke luar}

Arah campur kode ke luar merupakan campur kode yang terjadi karena menggunakan dua bahasa yaitu dengan mencampurkan bahasa utama yaitu bahasa Indonesia dengan bahasa asing. Terdapat dua arah di dalam novel Kami (Bukan) Sarjana Kertas karya J.S Khairen yaitu peggunaan bahasa Indonesia dengan bahasa Arab dan bahasa Indonesia dengan bahasa Inggris. Campur kode yang ditemukan dalam penggunan antara bahasa Indonesia dengan bahasa Arab dalam novel Kami (Bukan) Sarjana Kertas karya J.S Khairen yang tampak pada kutipan-kutipan di bawah ini.

(5) “Assalamualaaikum, aku Juwisa. Biasa dipanggil Wisa.” (KBSK, 2019: 34)

Ucapan “Assalamualaaikum” yang terdapat pada kutipan 5 tersebut merupakan kata sapaan yang berasaal dari bahasa Arab. Kata tersebut biasanya digunakan oleh umat muslim untuk menyapa di awal perjumpaan. Selanjutnya, penggunaan kata "alhamdulilah" yang merupakan pengungkapan rasa syukur yang berasal dari bahasa Arab juga terdapat dalam novel Kami (Bukan) Sarjana Kertas karya J.S Khairen, seperti pada kutipan di bawah ini.

(6) "Ya ndak apa-apa, kalau belum siap jawab aja. Kalau sudah ya alhamdulilah,"sergah ayah Juwisa. (KBSK, 2019: 204)

Berdasarkan kutipan 5 dan 6 di atas, terbukti adanya penggunaan campur kode ke luar yaitu penggunan antara bahasa Indonesia dengan bahasa Arab melalui ucap syukur yang dituturkan tokoh tersebut. Selanjutnya, campur kode yang ditemukan dalam penggunan bahasa Indonesia dengan bahasa Inggris lebih banyak jika dibandingkan dengan campur kode dengan bahasa lain yang telah dibahas sebelumnya. Tuturan $I$ know a story about you, from your friends dan What? Dilakukan sebagai penyandingan satu kalimat dan satu kata dengan penjelasan menggunakan bahasa Indonesia.

(7) "I know a story about you, from your friends, cerita tentang bagaimana kamu bisa kuliah di sini. Kamu tidak kasihan dengan ayah dan ibumu?" (KBSK 2019: 61) 
(8) “What? Mesti instal ulang ya? (KBSK, 2019: 310)

Berdasarkan kutipan 7 dan 8 dapat diketahui bahwa dalam novel Kami (Bukan) Sarjana Kertas karya J.S Khairen terdapat kutipan yang mengandung unsur campur kode ke luar yakni penggunaan percampuran bahasa Indonesia dengan bahasa Inggris. Percampuran tersebut terjadi pada percakapan yang terjadi antara tokoh dengan menggambarkan kehidupan ibu kota Jakarta, khususnya keharusan dalam mempelajari dan mampu menggunakan bahasa Inggris dalam kehidupan sehari-hari, tetapi penerapannya belum bersesuaian artinya dilakukan pencampuran bahasa asing dengan bahasa keseharian atau bahasa ibu sebagai bentuk keakraban.

Penggunaan percampuran bahasa Ibu ke bahasa kedua dapat menimbulkan interferensi. Wibowo (2003: 11) menyatakan bahwa interferensi adalah pengacauan bahasa yang terjadi dalam diri orang yang berbilingual dan multilingual. Rohmani, dkk. (2013: 6) menambahkan alih kode dan campur kode dapat juga terjadi pada wacana tulis termasuk karya sastra yang didasari oleh sebab-sebab tertentu seperti keindahan bahasa atau pembentukan karakter tokoh meski terkadang berakibat pada penyimpangan bahasa.

Kewajaran dalam penyimpangan bahasa dalam karya sastra juga disepakati oleh AlMa'ruf (2009) menerangkan jika penyimpangan kebahasaan dalam sastra dilakukan pengarang dimaksudkan untuk mendapatkan dampak estetis serta mengaktualkan sesuatu yang dituturkan. Bahasa sastra dengan demikian bertabiat dinamis, terbuka terhadap kemungkinan adanya penyimpangan serta pembaruan, tetapi juga tidak mengabaikan aspek komunikatifnya.

\section{SIMPULAN}

Berdasarkan penjelasan di atas, dapat didapatkan suatu kesimpulkan bahwa dalam novel Kami (Bukan) Sarjana Kertas karya J.S Khairen terdapat dua arah campur kode, yaitu campur kode ke dalam dan campur kode ke luar. Campur kode ke dalam yang ditemukan yaitu adanya percampuran antara bahasa Indonesia dengan bahasa Jawa dan bahasa Indonesia dengan bahasa Betawi. Selanjutnya, dalam campur kode ke luar terdapat dua arah, yaitu : penggunaan bahasa Indonesia dengan bahasa Arab dan bahasa Indonesia dengan bahasa Inggris.

\section{DAFTAR RUJUKAN}

Al-Ma'ruf, A.I. (2009). Stilistika: Teori, Metode, dan Aplikasi Pengkajian Estetika Bahasa. Solo: Cakra Books.

Meldani, A. (2018). Alih Kode dan Campur Kode dalam Novel The Sweet Sins Karya Rangga Wirianto Putra. Jurnal Bapala. Vol. 05 (1), 1-11.

Chaer, A. (2012). Linguistik Umum. Jakarta: Rineka Cipta.

Chaer. A., \& Agustina, L. (2014). Sosiolinguistik. Jakarta: Rineka Cipta. 
Malabar, S. (2015). Sosiolinguistik. Gorontalo: Ideas Publishing.

Maulina, dkk. (2018). Analisis Alih Kode dan Campur Kode dalam Novel Bumi Cinta Karya Habiburrahman El Shirazy. Jurnal Pendidikan dan Pembelajaran Khatulistiwa. Vol. 7 (9), 1-10.

Moleong, L. J. (2012). Metodologi Penelitian Kualitatif. Bandung: Remaja Rosdakarya.

Muhadjir. (2000). Bahasa Betawi Sejarah dan Perkembangannya. Jakarta: Yayasan Obor Indonesia.

Mulyani, S., \& A.S. H (2015). Teori Belajar Bahasa. Tangerang: Pustaka Mandiri.

Mutmainnah, Y. (2008). Pemilihan Kode dalam Masyarakat Dwibahasa: Kajian Sosiolinguistik pada Masyarakat Jawa di Kota Botang Kalimantan Timur. Tesis: Program Studi Magister Linguistik. Fakultas Ilmu Budaya, Universitas Diponegoro Semarang.

Nasruddin. (2015). Sosiolinguistik. Sulawesi: Read Institute Press.

Nursaid, \& Maksan, M. (2002). Sosiolinguistik. FBBS: UNP Press.

Rohmani, dkk. (2013). Analisis Alih Kode dan Campur Kode Pada Novel Negeri 5 Menara Karya Ahmad Fuadi. Jurnal Basastra. Vol. 2 (1), pp: 1-16.

Rokhman, F. (2013). Sosiolinguistik: Suatu Pendekatan Pembelajaran Bahasa dalam Masyarakat Multikultural. Yogyakarta: Graha Ilmu.

Rosnaningsih, A. (2019). Analisis Campur Kode dan Alih Kode Bahasa Inggris ke dalam Bahasa Indonesia pada Novel Wandu Berhentilah Menjadi Pengecut Karya Tasaro. Jurnal Lingua Rima. Vol. 8 (2), 25-32.

Sumarsono. (2007). Sosiolinguistik. Yogyakarta: Pustaka Pelajar.

Suryabrata, S. (2012). Metodologi Penelitian. Jakarta: RajaGrafindo Persada.

Wardani, O. P. (2017). Campur Kode dan Alih Kode Nilai-Nilai Islam dalam Novel Padang Bulan Karya Andrea Hirata. Jurnal Bahasa Sastra dan Pengajarannya. Vol. 1 (1), 74-89.

Wibowo, W. (2003). Manajemen Bahasa. Jakarta: Gramedia Pustaka Utama.

Yuliyanti, A. A. (2018). Prinsip Kerja Sama dan Implikatur Pada Tuturan Alih Kode dalam Film-Film Jerman. Jurnal Belajar Bahasa. Vol. 3 (2), 127-140. 